\title{
Closing the
}

Courthouse Door 
This page intentionally left blank 


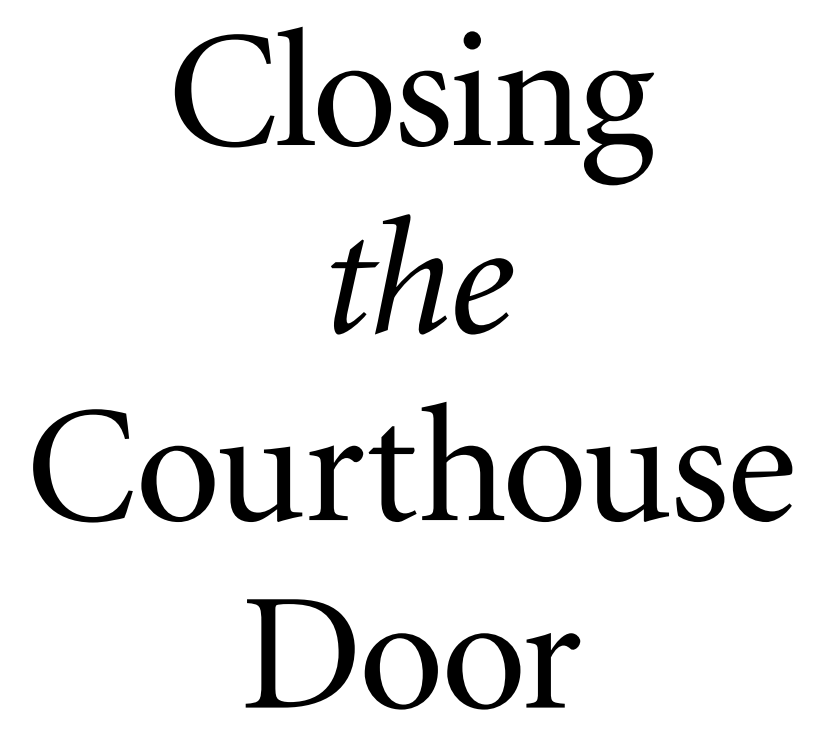

How Your Constitutional Rights

Became Unenforceable

ERWIN CHEMERINSKY

Yale university PRESS/NEW HAVEN \& LONDON 


\section{Copyright $\odot 2017$ by Erwin Chemerinsky.}

All rights reserved.

This book may not be reproduced, in whole or in part, including illustrations, in any form (beyond that copying permitted by Sections 107 and 108 of the U.S. Copyright

Law and except by reviewers for the public press), without written permission from the publishers.

Yale University Press books may be purchased in quantity for educational, business, or promotional use. For information, please e-mail sales.press@yale.edu

(U.S. office) or sales@yaleup.co.uk (U.K. office).

Set in Minion type by Newgen North America. Printed in the United States of America.

ISBN 978-0-300-21158-o (hardcover : alk. paper)

Library of Congress Control Number: 2016941955

A catalogue record for this book is available from the British Library.

This paper meets the requirements of ANSI/NISO Z39.48-1992

(Permanence of Paper).

10987654321 
For Catherine 
This page intentionally left blank 